\title{
Effect of Early Post-Hatch Feeding Time on Growth and Carcass Performance of Mule Ducks Reared Intensively in the Humid Tropics
}

Review

-Author(s)

Willians MA' (iD https://orcid.org/0000-0001-8682-9597 Lallo CHO" (D) https://orcid.org/0000-0001-5499-8257

Department of Food Production, Faculty of Food and Agriculture.

Open Tropical Forage and Animal-Production Laboratory, Department of Food Production Faculty of Food and Agriculture - The University of the West Indies St. Augustine Campus.

\section{Mail Address}

Corresponding author e-mail address Melissa A. Williams

University of the West Indies at Saint Augustine - Food Production - St.Augustine Trinidad West Indies Saint Augustine 00000 - Trinidad and Tobago.

Phone: 18684780095

Email: akeela.williams08@gmail.com

\section{- Keywords}

Carcass evaluation, feed conversion, growth performance, Mule ducklings, $\mathrm{pH}$.

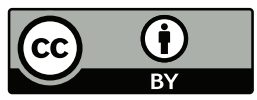

Submitted: 28/December/2019 Approved: 03/July/2020

\section{ABSTRACT}

A prolonged period without feed access negatively impacts the growth and development of poultry. This study evaluated the effect of early post-hatch feeding times on the growth and carcass performance of Mule ducks reared intensively in the tropics. A total of 48 Mule ducklings were obtained from a local hatchery and assigned in a completely randomized design to 4 treatments based on 4 feeding regimes, (T) as follows: T1 3hrs, T2 24hrs, T3 36hrs and T4 48hrs posthatch. On day 1 the ducklings were individually weighed, followed by weekly weighing until harvest at 63 days. Feed and feed refusal was measured daily for a period of 63 days. At harvest the body weight at slaughter, eviscerated and hot carcass weight, as well as the initial pH and $\mathrm{pH}_{24}$ of the breast, leg, and thigh quarters was evaluated. Weights of the organs of the gastrointestinal tract were then taken. The feed conversion ratio $(F C R)$, feed intake and meat: skin: bone ratio was calculated. At 0-7 days cumulative feed intake and FCR was influenced by treatment ( $p=0.022, p=0.026$; respectively). Body weight at slaughter ranged from 2969-3382.5g. Treatment did not affect the weights of the bone, fat, muscle and skin, of the breast quarter ( $p=0.698, p=0.893$, $p=0.940$; respectively). However, weight of the bone for the leg and thigh quarter differed among treatments. A lower $\mathrm{pH}_{24}$ was observed for both breast and leg and thigh quarters. The study suggests that early post-hatch feeding at 3-48hrs does not affect the performance of Mule ducks.

\section{INTRODUCTION}

In Trinidad and Tobago, duck production is generally done on a subsistence level with farmers rearing ducks in their backyards. Further, there has been an increase in the demand for duck meat partly due to the influx of Chinese restaurants, as well as an improvement in housing development and technology. This has led to the expansion of the sector towards more commercial semi-intensive and intensive operations (Lallo \& Ramraj, 2008). Moreover, the move towards inclusion of ducks into supermarket chains has led to a demand for improved quality carcasses (Lallo \& Ramraj, 2008). Additionally specialization within the industry has seen the emergence of hatchery operations as well as increases in the number of grow-out operations (Lallo et al., 2007). However, there is currently a lag time in the movement of birds from the hatchery to the grow-out operations. This increase in holding time post-hatch without access to feed has been said to have a negative effect on the growth and development of poultry (Noy \& Sklan, 2001). One major disadvantage of delayed feeding is body weight loss due to a decrease in the weights of tissues and organs (Nir \& Levanan, 1993).

Early post -hatch feeding has been noted to stimulate the growth of the gastrointestinal tract and its absorptive capacity (Saki, 2005); 
thereby significantly affecting growth, feed efficiency, uniformity, carcass yield and cost of production (Saki, 2004). A perusal of the literature has shown that this same practice is not studied in Mule ducks. In light of this, this study sought to evaluate the effect of early post-hatch feeding times on the growth and carcass performance of Mule ducks reared intensively in the tropics.

\section{MATERIALS AND METHODS}

\section{Location and Climate}

Trinidad is located within the humid tropics at 10 $1 / 2^{\circ}$ North latitude and $61 / 2^{\circ}$ West longitude. Daily temperatures range between $24.1-36.15{ }^{\circ} \mathrm{C}$ and average humidity of 80.21 . There are two seasons: a dry season from January to May and a rainy season from June to December. The experiment was conducted during the wet season at The University of the West Indies' Field Station (UFS) located in Valsayn (10 $38^{\prime} 15^{\prime \prime}$ North $61^{\circ} 25^{\prime} 39^{\prime \prime}$ West) a town in north Trinidad.

\section{Animals and Experimental Design}

A total of 48 Mule ducklings were obtained from a local hatchery and assigned in a completely randomized design to four treatment groups based on four feeding regimes, (T) as follows: T1 3h, T2 24h, T3 36h and T4 48h post-hatch. Each treatment group comprised of 6 replicates with 2 ducklings each. On Day 1 the ducklings were individually weighed, followed by weekly weighing until 63 days. Each treatment was replicated six times with a total of 2 ducklings per replicate (12 ducklings per treatment). They were raised in an open sided naturally ventilated house in cages of dimension: Length $122 \mathrm{~cm} \times$ Width $61 \mathrm{~cm}$ and a stocking density of 2 birds $/ \mathrm{m}^{2}$ was used. Treatment 1 received both water and feed 3hrs post-hatch while the other treatments received no feed until 24, 36 and $48 \mathrm{hrs}$, post-hatch, respectively. Feed offered was given according to National Research Council standards (NRC, 1994) and refusal was measured daily in order to determine feed intake while water was given ad libitum. No vaccination was done in accordance with local production practices.

\section{Diet}

A commercial duck ration formulated primarily from soybean and corn was weighed and fed to the ducks once a day. Table 1 gives chemical composition of diet fed. Ducklings were fed starter ration for 21 days and from 22 days the ducks were fed a grower ration until 63 days.
Table 1 - Composition of Starter and Grower Diet.

\begin{tabular}{lcc}
\hline Ingredients (g/kg-1 DM) & Starter & Grower \\
\hline Soyabean Meal (470g CPkg $\left.{ }^{1} \mathrm{DM}\right)$ & 415.2 & 251.2 \\
\hline Ground corn & 356.4 & 548.1 \\
\hline Rice Bran & 80.0 & 100.0 \\
\hline Broken Rice & 60.6 & 0 \\
\hline Bran Shorts & 30.0 & 45.0 \\
\hline Soyabean Oil & 15.0 & 15.0 \\
\hline Dicallcium Phosphate & 13.5 & 11.4 \\
\hline Limestone & 12.8 & 14.5 \\
\hline Broiler Premix-9943 & 7.5 & 7.5 \\
\hline NACI (salt) & 4.6 & 2.8 \\
\hline Bentonite & 3.0 & 3.0 \\
\hline Luprosil Salt & 0.9 & 0.9 \\
\hline Methionine dl & 0.4 & 0.6 \\
\hline Calculated Chemical Composition (g/kg-1 DM) & \\
\hline Dry Matter* & 889 & 893 \\
ME (kcalg-1 DM) & 2.850 & 3.038 \\
\hline Crude Protein* & 224 & 178 \\
\hline NDF* & 164 & 330 \\
\hline Ca & 10.5 & 10.5 \\
\hline Available P & 4.6 & 4.0 \\
\hline Ca: Available P & 2.3 & 2.6 \\
\hline Lysine & 15.0 & 10.6 \\
\hline Methionine & 4.66 & 4.05 \\
\hline Methionine + Cysteine & 9.16 & 7.666 \\
\hline Tryptophan & 3.55 & 2.48 \\
\hline ME/P & 12.7 & 17.1 \\
\hline Feed Pellet Quality Factor (FPQF) & Crumble & 3.8 \\
\hline
\end{tabular}

\section{Animal Management}

The mean $( \pm$ SEM) initial weights of the ducklings for each treatment were: T1: $51.83 \mathrm{~g} \pm 3.98$, T2: $51.17 \mathrm{~g} \pm 7.14, \mathrm{T3}: 51.92 \mathrm{~g} \pm 3.47$ and T4: $51.42 \mathrm{~g} \pm 3.75$. The ducks were observed on a daily basis for problems with pests and diseases. At 7 days the ducklings were weighed using an electronic scale (OHAUS IR SENSOR). This procedure was repeated weekly until harvest age (63 days). Feed conversion ratio (FCR) during the respective weeks and the overall period was calculated as the ratio between units feed intake and unit weight gain.

\section{Carcass Evaluation}

At the end of the experiment (63 days), the ducks from each treatment were weighed and labeled for subsequent identification. This weight was recorded as the live weight/ body weight at slaughter. The ducks were then euthanized according to the APA 2000 Ethics Code using the cervical dislocation. The feathers and the internal organs were then removed and the eviscerated carcass weight was taken. The weight of the liver, gizzard, proventriculus and small and large intestines were taken and recorded. The head and feet 
of the ducks were removed and the weights of the carcasses were taken, this weight was referred to as the hot carcass weight. Using a handheld $\mathrm{pH}$ meat meter (Hannah, Model HI99163) the pH of the breast, leg and thigh of the carcasses was taken and recorded. This procedure was repeated at 24 hours $\left(\mathrm{pH}_{24}\right)$. The carcasses were then physically separated into wings, breasts, leg and thigh quarters and neck and back. Each component was weighed and recorded. The skin and subcutaneous fat was removed from the muscles and the muscles removed from the bone for each component. They were then weighed and recorded in order to determine a meat:skin:bone ratio.

\section{Statistical Analysis and Calculation}

The data was subjected to a one way Analysis of Variance (ANOVA) and mean separation (Fisher's pair- wise comparison) was done using Minitab Release 18 for Windows (Minitab 2017).

\section{RESULTS}

\section{Growth Performance}

Table 2 below shows the effects of early posthatch feeding on the performance of Mule ducks reared intensively at the University Field Station. At 0-7 days cumulative feed intake and feed conversion was affected by treatment $(p=0.022),(p=0.026)$; respectively. Cumulative feed intake was observed to be the highest in the group fed at 36hrs post-hatch and the lowest in those fed at 48hrs. Whereas, at 0-21 and 0-63 days post-hatch feeding times did not impact on the body weight, cumulative feed intake and FCR.

Table 2 - The effect of early post hatch feeding on the performance of Mule ducks reared to 63 days.

\begin{tabular}{|c|c|c|c|}
\hline Treatment (hours) & Body weight (g) & Cumulative Feed Intake (g) & Feed conversion \\
\hline \multicolumn{4}{|l|}{$0-7$ days } \\
\hline 3 hours & $119.17^{a}$ & $84.50^{a}$ & $0.71^{a}$ \\
\hline 24 hours & $129.17^{a}$ & $73.42^{\mathrm{ab}}$ & $0.57^{\mathrm{ab}}$ \\
\hline 36 hours & $122.50^{a}$ & $71.25^{\mathrm{ab}}$ & $0.59^{\mathrm{ab}}$ \\
\hline 48 hours & $119.58^{a}$ & $63.88^{b}$ & $0.55^{b}$ \\
\hline \pm SEM & 0.804 & 0.646 & 0.611 \\
\hline$p$-value & 0.694 & 0.022 & 0.026 \\
\hline \multicolumn{4}{|l|}{$0-21$ days } \\
\hline 3 hours & $477.1^{\mathrm{a}}$ & $681.9^{a}$ & $1.53^{\mathrm{a}}$ \\
\hline 24 hours & $562.5^{a}$ & $603.9^{a}$ & $1.10^{\mathrm{a}}$ \\
\hline 36 hours & $505.4^{\mathrm{a}}$ & $563.4^{\mathrm{a}}$ & $1.16^{\mathrm{a}}$ \\
\hline 48 hours & $568.8^{a}$ & $572.4^{\mathrm{a}}$ & $1.01^{\mathrm{a}}$ \\
\hline \pm SEM & 0.122 & 1.861 & 0.115 \\
\hline$p$-value & 0.375 & 0.106 & 0.065 \\
\hline \multicolumn{4}{|l|}{$0-63$ days } \\
\hline 3 hours & $3102.9^{a}$ & $6500^{a}$ & $2.11^{a}$ \\
\hline 24 hours & $3039^{a}$ & $6589^{a}$ & $2.27^{\mathrm{a}}$ \\
\hline 36 hours & $3077^{a}$ & $6045^{a}$ & $1.96^{\mathrm{a}}$ \\
\hline 48 hours & $3051.5^{a}$ & $5774.8^{a}$ & $1.90^{\mathrm{a}}$ \\
\hline \pm SEM & 7.25 & 16.11 & 0.355 \\
\hline$p$-value & 0.975 & 0.669 & 0.748 \\
\hline
\end{tabular}

abRows with different superscript letters indicate differences between means of treatments $(p>0.05)$.

\section{Carcass Evaluation}

Table 3 below shows the effect of four different post-hatch feeding times on the carcass performance of Mule ducks. At 24hrs post slaughter only the body weight at slaughter was affected by treatment. No significant difference ( $p>0.05$ ) was observed between treatments for carcass components, organ weights of the gastrointestinal tract (gizzard, proventriculus, and liver) and intestines. However, post-hatch feeding times were noted to influence the weight of the whole wing of Mule ducks.

\section{Physically-Separated Components}

Table 4 shows the effect of four different post-hatch feeding times on the physically-separated components of the carcass of Mule ducks reared to 63 days. Significant differences were noted among treatments $(p=0.005)$ on the wing portion ( $\mathrm{g} / 100 \mathrm{~g}$ eviscerated carcass weight) but there was no significant difference for the skin, fat, meat and bone of the breast among the treatments. The bone of the leg and thigh quarter differed $(p=0.000)$ between treatment groups. No difference was observed among treatment groups 
Table 3 - The effect of early post-hatch feeding on the carcass performance of Mule ducks grown to 63 days.

\begin{tabular}{|c|c|c|c|c|c|c|}
\hline Weights (g) & & & ent & & \pm SEM & $p$-value \\
\hline Post Hatch Feeding Time & 1 (3hrs) & 2 (24hrs) & 3 (36hrs) & 4 (48hrs) & & \\
\hline Body weight at slaughter (g) & $3342.2^{\mathrm{ab}}$ & $2969^{b}$ & $3382.5^{a}$ & $3260.8^{\mathrm{ab}}$ & 2.5 & 0.027 \\
\hline Eviscerated carcass (g) & $2366.7^{a}$ & $2182^{a}$ & $2456.7^{a}$ & $2374.2^{\mathrm{a}}$ & 2.2 & 0.095 \\
\hline Hot carcass weight (g) & $2280.8^{a}$ & $2129^{a}$ & $2358.3^{\mathrm{a}}$ & $2301.7^{a}$ & 2.2 & 0.195 \\
\hline Chilled carcass weight at 24 hours ( $\mathrm{g}$ ) & $2258.3^{a}$ & $2093^{a}$ & $2360^{a}$ & $2294.2^{a}$ & 0.09 & 0.101 \\
\hline Whole wing (g) & $302.5^{\mathrm{a}}$ & $298.33^{b}$ & $394.2^{b}$ & $314.17^{b}$ & 1.04 & 0.001 \\
\hline Whole breast (g) & $588.3^{a}$ & $615^{a}$ & $620.8^{a}$ & $659.2^{\mathrm{a}}$ & 1.4 & 0.480 \\
\hline Whole Leg (g) Quarters & $427.5^{\mathrm{a}}$ & $383.3^{a}$ & $465.8^{a}$ & $421.7^{a}$ & 1.4 & 0.319 \\
\hline Neck and back (g) & $867.5^{\mathrm{a}}$ & $805^{a}$ & $895^{a}$ & $848.3^{a}$ & 1.65 & 0.467 \\
\hline Proventriculus (g) & $10^{\mathrm{a}}$ & $10^{a}$ & $6.67^{\mathrm{a}}$ & $9.167^{a}$ & 0.3 & 0.421 \\
\hline Gizzard (g) & $63.6^{a}$ & $62.50^{\mathrm{a}}$ & $67.5^{\mathrm{a}}$ & $72.5^{\mathrm{a}}$ & 0.6 & 0.604 \\
\hline Liver (g) & $45.83^{\mathrm{a}}$ & $46.67^{a}$ & $46.67^{a}$ & $45^{\mathrm{a}}$ & 0.4 & 0.953 \\
\hline Intestines (large and small) (g) & $107.50^{\mathrm{a}}$ & $98.33^{\mathrm{a}}$ & $87.50^{a}$ & $105.8^{\mathrm{a}}$ & 0.6 & 0.075 \\
\hline Dressing percentage $(\mathrm{g} / \mathrm{kg})$ & $67.58^{\mathrm{a}}$ & $70.489^{a}$ & $69.7^{\mathrm{a}}$ & $70.3^{\mathrm{a}}$ & 0.61 & 0.050 \\
\hline
\end{tabular}

The carcass weight was inclusive of the neck.

${ }^{a b}$ Rows with different superscript letters indicate differences between means of treatments $(p>0.05)$.

Table 4 - The effect of early post-hatch feeding on physically-separated components of breast and leg quarters of Mule ducks at 63 days.

\begin{tabular}{|c|c|c|c|c|c|c|}
\hline \multirow{2}{*}{$\begin{array}{l}\text { Weights (g) } \\
\text { Post-Hatch }\end{array}$} & \multicolumn{4}{|c|}{ Treatment } & \multirow[t]{2}{*}{ \pm SEM } & \multirow[t]{2}{*}{$p$-value } \\
\hline & 1 & 2 & 3 & 4 & & \\
\hline \multicolumn{7}{|l|}{ Feeding times } \\
\hline \multicolumn{7}{|l|}{ Breast: } \\
\hline Skin + fat (g) & $107.5^{\mathrm{a}}$ & $100.8^{a}$ & $98.3^{a}$ & $108.3^{a}$ & 0.96 & 0.940 \\
\hline Meat (g) & $355.8^{a}$ & $335.8^{a}$ & $358.3^{a}$ & $347.5^{a}$ & 1.2 & 0.893 \\
\hline Bone (g) & $134.2^{\mathrm{a}}$ & $142.50^{\mathrm{a}}$ & $144.17^{\mathrm{a}}$ & $150^{a}$ & 0.80 & 0.698 \\
\hline \multicolumn{7}{|l|}{ Leg + Thigh } \\
\hline \multicolumn{7}{|l|}{ Quarter: } \\
\hline Skin + fat (g) & $108.3^{a}$ & $78.3^{a}$ & $78.3^{\mathrm{a}}$ & $97.5^{\mathrm{a}}$ & 0.88 & 0.207 \\
\hline Meat (g) & $239.17^{a}$ & $225^{a}$ & $238.3^{\mathrm{a}}$ & $249.17^{a}$ & 0.79 & 0.350 \\
\hline Bone $(\mathrm{g})$ & $95^{a}$ & $75^{b}$ & $81.67^{b}$ & $75.83^{b}$ & 0.42 & 0.000 \\
\hline
\end{tabular}

${ }^{a b R o w s ~ w i t h ~ d i f f e r e n t ~ s u p e r s c r i p t ~ l e t t e r s ~ i n d i c a t e ~ d i f f e r e n c e s ~ b e t w e e n ~ m e a n s ~ o f ~ t r e a t m e n t s ~}(p>0.05)$.

for skin and fat, meat and bone of the leg and thigh quarter. It was also observed that the breast yield, leg and thigh quarter, neck and back did not differ significantly among treatments (as seen in Table 5).
The organs of the gastrointestinal tract: proventriculus, gizzard, liver and intestines as $\mathrm{g} / 100 \mathrm{~g}$ of the eviscerated carcass weights were not different among treatments $(p>0.05)$.

Table 5 - The effect of post hatch feeding on the carcass yield of Mule ducks.

\begin{tabular}{|c|c|c|c|c|c|c|}
\hline Weights (g) & Treatment & & & & \pm SEM & $p$-value \\
\hline & 1 & 2 & 3 & 4 & & \\
\hline BreastYield (g/100g EVC) & $17.61^{\mathrm{a}}$ & $20.75^{\mathrm{a}}$ & $18.40^{\mathrm{a}}$ & $20.18^{a}$ & 0.63 & 0.043 \\
\hline LegQuarter ( $g / 100 g$ EVC) & $12.80^{\mathrm{a}}$ & $12.90^{\mathrm{a}}$ & $13.74^{\mathrm{a}}$ & $2.94^{\mathrm{a}}$ & 0.62 & 0.823 \\
\hline Wing $g / 100 \mathrm{~g}$ EVC & $9.08^{b}$ & $10.12^{\mathrm{ab}}$ & $11.62^{\mathrm{a}}$ & $9.64^{b}$ & 0.48 & 0.005 \\
\hline Neck\&Back g/100g EVC & $25.97^{\mathrm{a}}$ & $26.99^{a}$ & $26.50^{a}$ & $25.99^{a}$ & 0.65 & 0.812 \\
\hline Prov g/100g EVC & $0.30^{\mathrm{a}}$ & $0.35^{\mathrm{a}}$ & $0.20^{\mathrm{a}}$ & $0.28^{\mathrm{a}}$ & 0.15 & 0.221 \\
\hline Gizzard g/100g EVC & $1.91^{\mathrm{a}}$ & $2.12^{a}$ & $1.99^{a}$ & $2.23^{\mathrm{a}}$ & 0.30 & 0.603 \\
\hline Liver $\mathrm{g} / 100 \mathrm{~g}$ EVC & $1.38^{\mathrm{a}}$ & $1.58^{\mathrm{a}}$ & $1.38^{\mathrm{a}}$ & $1.38^{\mathrm{a}}$ & 0.19 & 0.206 \\
\hline Intestines g/100g EVC & $3.22^{\mathrm{a}}$ & $3.36^{a}$ & $2.59^{a}$ & $3.25^{\mathrm{a}}$ & 0.31 & 0.470 \\
\hline
\end{tabular}

ab Rows with different superscript letters indicate differences between means of treatments $(p>0.05)$.

The effect of four different post-hatch feeding times on the $\mathrm{pH}$ for breast and leg quarters of Mule is illustrated in Table 6 . The $\mathrm{pH}$ of the breast for hot carcass $(p=0.017)$ differed among treatments. However, post- hatch feeding times did not affect the $\mathrm{pH}$ of the leg quarters. No significant difference occurred among treatments of the $\mathrm{pH}$ of the breast and leg quarters of the Mule ducks at $24 \mathrm{hrs}$. 
Table 6 - The effect of post-hatch feeding on the pH of Breast and Leg Quarters of Mule ducks.

\begin{tabular}{|c|c|c|c|c|c|c|}
\hline \multirow[t]{2}{*}{$\mathrm{pH}$} & \multicolumn{4}{|c|}{ Treatment } & \multirow[t]{2}{*}{ \pm SEM } & \multirow[t]{2}{*}{$p$-value } \\
\hline & $1(3 \mathrm{~h})$ & $2(24 h)$ & $3(36 h)$ & $4(48)$ & & \\
\hline Breast $\mathrm{pH}$ value & $5.52^{\mathrm{ab}}$ & $5.45^{b}$ & $5.67^{a}$ & $5.43^{b}$ & 0.05 & 0.017 \\
\hline Leg Quarter $\mathrm{pH}$ value & $5.84^{a}$ & $5.77^{\mathrm{a}}$ & $5.81^{a}$ & $5.62^{a}$ & 0.07 & 0.261 \\
\hline Breast $\mathrm{pH}_{24 \text { hours }}$ & $4.33^{\mathrm{a}}$ & $4.29^{\mathrm{a}}$ & $4.39^{a}$ & $4.31^{\mathrm{a}}$ & 0.06 & 0.728 \\
\hline Leg Quarter $\mathrm{pH}_{24 \text { hours }}$ & $4.97^{a}$ & $5.04^{a}$ & $4.93^{\mathrm{a}}$ & $4.70^{\mathrm{a}}$ & 0.10 & 0.468 \\
\hline
\end{tabular}

abRows with different superscript letters indicate differences between means of treatments $(p>0.05)$.

\section{DISCUSSION}

\section{Growth Performance}

The results showed that at $0-7,0-21$ and $0-63$ days post-hatch feeding times had no effect on the body weight of ducks for this study (See Table 2). Contrastingly, Bhanja et al. (2009) reported that the body weight at 0-7, 0-21 and 0-35 days of broiler chicks was affected by the time of post-hatch feeding. However, ducks used in this study were grown to 63 days while broilers were grown to 35 days; thus the difference in market age may have attributed to the contrasting results. Body weight for ducks at 0-7 days ranged from $119.17-129.17 \mathrm{~g}$ which was slightly similar to the range observed for broiler chicks (106138g) at 0-7 days (Bhanja et al. 2009). Garden (2008) reported that the 7 day weight of broilers should be approximately 4-5 times the day old broiler chick's weight. Even though the 0-7 days weight of Mule ducklings were similar to broilers, the ducklings were observed to be less than 4.5 - 5 times the placement weight. This may be attributable to the difference in the placement weight of species.

At $0-21$ and $0-63$ days the body weight of ducks from this study was within a range of 477.1-568.8g and 3051.5-3102.9g; respectively. These results were incongruent to body weights of different strains of Pekin ducks and Muscovy at 0-21 days (1063, 1146 and $1118 \mathrm{~g}$; respectively) but similar to the Mule and Muscovy duck (3100 and 2378; respectively) at 0-63 days (Lallo \& Ramraj, 2008; Lallo et al., 2007). At 0- 63 days even though there was no significant difference among treatments, ducks from the group fed at 36hrs post-hatch had the highest body weight $(3102.9 \mathrm{~g})$ in comparison to ducks that were fed at 24, 36 and 48hrs (3039g, 3077g and 3051.5g; respectively). This result would suggest that there may have been some compensatory growth in the post 21 day period (Scott \& Dean, 1991). Additionally, early access to feed and water post-hatch may have led to the stimulation and development of the gastrointestinal tract causing an increase in the absorption surface area and nutrients assimilation. This contributes to overall muscle growth and body weight gain in the neonatal period and beyond of birds (Dibner et al., 1998; Noy \& Sklan, 1998; Viera \& Moran, 1999).

The results showed that at 0-7 days cumulative feed intake differed significantly among treatments $(p=0.022)$. At $0-63$ days, cumulative feed intake of ducks (5774.8-6589g) was lower than that of Mule strains and Muscovy (10726 and 7263g; respectively) grown to 95 days (Lallo et al., 2007). Cumulative feed intake was higher in the group of ducks fed at $3 \mathrm{hrs}$ post-hatch in comparison to those fed at 24, 36 and 48hrs. Similar to the findings of this study, Obun \& Osaguona (2013) reported that at 0-7 days post-hatch feeding times significantly affected the cumulative feed intake of broiler chicks.

At 0-7 days there was no difference noted among treatments for the feed conversion of ducks $(p=0.026)$. Contrastingly, Ganja et al., (2015) found that the feed conversion ratio (FCR) of birds fed at 6hrs post-hatch were significantly superior $(p<0.05)$ to those with access to feed at 12 and 18hrs. The feed conversion at 0-7 days for ducks from this study ranged from 0.55 to 0.71 . Concomitant to the findings of this present study, Bhanja et al. (2009) reported that at 0-7 days broiler chicks feed conversion ratio ranged from 0.86-0.96. The FCR when compared to other species of ducks at 0-21 days was lower (1.01-1.53) than local (2.00) and international (2.21) Pekin strain and Mule strain from Canada (2.29) (Lallo \& Ramraj, 2008). However, similar observations were made at 0-63 days in which the FCR of ducks in this study was slightly lower than the Mule and Muscovy ducks used by Lallo et al. (2007). The ducks all had a FCR ranging from $1.90-2.27$ at $0-63$ days. The strain of ducks used was the Mulard Hytop 82 which was imported from Canada, while the strains used by Lallo \& Ramraj (2008) and Lallo et al. (2007) came from Maple Leaf farm USA, Les Simetin of Canada, Trinidad and Tobago and Grimaud Freres of France. Muscovy and their crosses generally utilize feed more efficiently than White Pekin crosses at all ages; this may further explain the differences in FCR observed (Hetzel, 1983). The relative performance of ducks is 
dependent upon both strain and environment (Scott \& Dean, 1991). Cumulative feed intake and FCR of the ducks was found to be higher in the group that was fed at 3hrs in comparison to those fed at 24, 36 and $48 \mathrm{hrs}$. This finding highlighted the need for an economic evaluation to be done in order to further explain the significance of such discovery.

\section{Carcass Evaluation}

The body weight of the Mule ducks at slaughter was significantly $(p=0.027)$ affected by post-hatch feeding (See Table 3). Further, the group of ducks that were exposed to feed at 36hrs post-hatch showed the highest body weight at slaughter $(3382.5 \mathrm{~g})$ in comparison to those that were fed at 3, 24 and 48hrs. This result supports the claim by Cateel et al. (1994); Hager \& Beane (1983); Noy \& Sklan (1999b) that one of the major consequences of delayed access to feed is body weight loss. However, the results were not in keeping with those found for broilers (Obun \& Osaguona, 2013). The market age used for broilers was 42 days while 63 days was the age at which ducks from this study was harvested; thus giving the ducks time to compensate in growth (Scott \& Dean, 1991). This difference in grow-out age between species may have contributed to the contrast between the results observed.

The ducks fed at 36hrs post-hatch gained 1.2, 12.2 and $3.6 \%$ more weight than those deprived of feed for 3, 24 and 48hrs. This result was not in agreement with Gonzales et al. (2003) for broiler chicks; in which broilers were $8-10 \%$ heavier than those held without feed or given water only This result observed may be attributable to the level of growth recovery after a period of feed deprivation (Gonzales et al., 2003). At 0-63 days, body weight of ducks fed at 3, 24, 36 and 48hrs post-hatch was not affected by the feeding times; however the difference between body weights at slaughter would suggest that there was some compensatory growth (Scott \& Dean, 1991). At 63 days, the ducks observed all had body weights at slaughter ranging from 2969-3382.5g and were not similar to that reported for Mule and GrimaudFreres Strain at 95 days in which the body weight at slaughter was 3680, 3775 and 3605g (Lallo et al. (2007). This difference observed may be attributed to the strain of ducks used as well as the market age. However, the body weights at slaughter of ducks from this study was closer to Mule strains from Canada and Maple Leaf Farm USA (3078 and 2987; respectively) which were harvested at 70 days.
Eviscerated carcass weight of the Mule ducks ranged from 2182 to $2456.7 \mathrm{~g}$ and showed no significant differences among treatments $(p=0.095)$. This result was not in keeping with the weight of eviscerated carcass obtained for Mule and both local and imported Pekin strains harvested at 70 and 49 days (Lallo et al. (2007). However, at the time the eviscerated carcass weight was taken the neck of the ducks were still attached which may have contributed to the differences in weights observed by Lallo et al. (2007) for Mule and Pekin duck strains.

Post-hatch feeding times did not significantly influence the breast yield of the ducks observed. This result showed disagreement with Halevy et al., for broilers (2003) in which delayed feeding caused a decline in breast muscle weight through to market age. The breast yield of Mule ducks for this study fell within a range of 588.3-659.2g for all treatment groups (3, $24,36,48$ hrs). Further it was seen that the breast meat yield of the group fed at 48 hrs post-hatch had the highest weight $659.2 \mathrm{~g}$. This result did not support the claim by Noy \& Sklan (1998); Careghi et al. (2005); Tweed (2005) for broilers. However, the difference among treatments observed may be correlated to the $\mathrm{pH}$ value. Since the $\mathrm{pH}$ influences the drip loss (water holding capacity) and impacts on the overall weight of the breast yield (Van Laack, 2000).

The weight of the wing for the ducks ranged from 298.33-394.2g. These weights were similar to the Muscovy and Pekin ducks but different to the weights of the wing of Mule ducks grown to 95 days (Lallo et al., 2007).

Results of the study showed that post-hatch feeding times $(3,24,36,48 \mathrm{hrs})$ did not have an effect on the weights of the proventriculus $(p=0.421)$, gizzard $(p=0.604)$, liver $(p=0.953)$, and intestines $(p=0.075)$. This result supports the claim by El-Husseiny et al. (2008). Similarly, Petek et al. (2007) reported that posthatch feeding times $(0,18,36 \mathrm{hrs})$ had no significant impact on the parameters of liver and gizzard of broilers.

Post-hatch feeding time did not significantly impact on the weight of the intestines for Mule ducks; however this result was not similar to results obtained for broilers harvested at 42 days (Abed et al., 2011). The intestine of the ducks observed at 63 days was inclusive of both small and large intestines which probably contributed to the difference in results.

The dressing percentage of the ducks observed was $67.58,70.489,69.7$ and $70.3 \%$ for treatments 1,2 , 3 , 4; respectively. These dressing percentages when 
compared to both broilers and turkeys were found to be closer to that of broilers (71\%) than turkeys (79\%) (Schweihofer, 2011, sourced from Kendall, 2001). Similarly the dressing percentage of ducks from this study fell within similar range as other breeds of ducks in Nigeria (Omojola, 2007).

\section{Physically-Separated Components}

Carcass composition differs in the weight, fat content, muscle and bone of various species (Irshad et al., 2012). Moreover, procedures used to measure carcass composition in ducks have varied among different researchers (Wilson, 1975; Veltman \& Sharlin, 1981) making it difficult to compare results. The skin and fat, meat and bone in the breast yield were not significantly affected by post-hatch feeding times in this study ( $p=0.940, p=0.893, p=0.698$ ). The breast yield for ducks (See Table 4) (g/100g EVC) ranged from $17.611020 .75 \mathrm{~g}$ and was found to be lower than strains of Mule ducks grown to 70 days (Lallo \& Ramraj, 2008). Likewise, the leg and thigh yields of Mule ducks ranged from 12.80, 12.90, 13.74, 12.94g/ $100 \mathrm{~g}$ EVC for treatments 1, 2, 3 and 4; respectively. These values fell outside the range observed by Lallo \& Ramraj (2008) for two different strains of Mule ducks (17.7 and $18.7100 \mathrm{~g} \mathrm{EVC}$ ). This difference may be attributable to the difference in harvest age which was 70 days for ducks from Lallo \& Ramraj (2008) and 63 days for Mule ducks.

Various breeds and strains of ducks show differences in carcass composition; this species, like the goose and swine, is normally fat. Ducks normally deposit thick layers of subcutaneous and abdominal fat. The ducks under observation all had skin and fat (as grams per $100 \mathrm{~g}$ of the breast yield) values ranging from 15.8 to 18.3 and 16.8 to 25.3 (as $\mathrm{g} / 100 \mathrm{~g}$ of the leg and thigh yield) for the leg and thigh quarter, respectively. The skin and fat for both breast and leg and thigh yield were not different to that reported for Mule strains of Canada and Maple leaf farm USA (Lallo \& Ramraj, 2008).

The carcass tissue composition and meat quality of drakes and ducks of A44 strain reared to 9 weeks revealed that the meat: fat ratio was 1.01:1, meat: bone ratio 1.07:1 and the fat: bone ratio was 1.07:1 Witak (2008). However, the meat: skin: bone ratio of the breast yield for ducks from this present study was found to be 1:5:4, 1:6:4, 1:6:4, 1:6:4 for Treatments 1, 2,3 and 4; respectively. Whereas, for the leg and thigh quarter the ratio for $\mathrm{T} 1, \mathrm{~T} 2, \mathrm{~T} 3$ and $\mathrm{T} 4$ were 1:3:4, 1: 4: 5, 1: 5: 5 and 1: 4: 5; respectively. These results were slightly different to Witak (2008). As animals mature, both an increase of muscle to bone and fat to muscle ratio and a decrease in muscle growth rate occurs (Lawrie, 1998). This explanation may probably be the reason for the ratio observed for ducks from this study. However, a higher ratio is better since it equates to more saleable lean meat and better carcass conformation (Irshad et al., 2012).

\section{pH}

$\mathrm{pH}$ and the ultimate $\mathrm{pH}\left(\mathrm{pH}_{24}\right)$ are extremely important indicative parameters of meat quality since there is a correlation between $\mathrm{pH}$ value and poultry meat quality (Ristic \& Freudenreich, 2006). The major attributes which define the quality of poultry and other types of meats are appearance, texture, juiciness, flavor and functionality all of which are influenced by $\mathrm{pH}$ (Glamoclija et al., 2015). In this study the $\mathrm{pH}$ of the breast quarter of ducks (hot carcass) ranged from 5.45- 5.67 (See Table 5) and was slightly similar to the range of 5.6-5.9 for broilers (Rose, 1997). This study also found that the $\mathrm{pH}$ of the breast quarter differed among the treatment $(p=0.017)$ with ducks belonging to the group fed at 36hrs showing the highest $\mathrm{pH}$. The differences in $\mathrm{pH}$ observed may be explained by Van Laack \& Kauffman (1999); Van Laack et al. (2000). These authors stated that even though muscles may have the same lactate concentration these muscles may have different $\mathrm{pH}$ and is determined by the glycogen concentration.

The $\mathrm{pH}$ of the leg and thigh quarter of ducks in this study all fell within the range of 5.62-5.84; however when compared to broilers the results were not similar. Since the $\mathrm{pH}$ value can range from 5.2 to 7.0 for poultry meat and is influenced by both breed lines and species (Baeza, 1995) this may be the reason for the differences observed.

The $\mathrm{pH}_{24}$ of both the breast and leg and thigh quarter of the ducks ranged from 4.29-4.39, and 4.705.04; respectively. These values were lower than $\mathrm{pH}$ values obtained by Jacob \& Hopkins (2014) on Muscovy ducks. It was found that the $\mathrm{pH}_{24}$ for both breast and leg and thigh quarters were found to be 5.8 and 6.2; respectively. However, the ducks in this current study were raised in conditions that required little walking to access feed and water; thus contributing a high glycolytic potential which results in a low $\mathrm{pH}_{24}$ (Warris, 2010).

Chicken breast usually drops to a $\mathrm{pH}_{24}$ of 5.6- 5.9; whereas leg quarter drops to a $\mathrm{pH}_{24}$ of 6.1-6.4 (Rose, 1997). However, $\mathrm{pH}_{24}$ of the breast and leg quarter 
for ducks was observed to be lower than the $\mathrm{pH}_{24}$ for chickens. The low $\mathrm{pH}_{24}$ is caused by the anaerobic breakdown of glycogen and the production of lactic acid in the tissues (Van Laack \& Kaufman, 1999). This low $\mathrm{pH}$ is important for the keeping quality of the meat by reducing bacterial growth (Rose, 1997).

The ultimate $\mathrm{pH}_{24}$ was observed to be lower in the breast than in the leg and thigh quarter of ducks. However, $\mathrm{pH}_{24}$ varies between muscles since muscles throughout the carcass vary in their level of glycogen, the rates of energy metabolism as well as their rates of temperature and $\mathrm{pH}$ decline, due to inherent metabolic differences and muscle size (Lawrie, 1991). As the animal dies due to loss of blood and the resulting anoxia the muscle cells continue to respire, producing and consuming Adenosine Triphosphate (ATP) leading to an accumulation of lactic acid and a change in the $\mathrm{pH}_{24}$ (Baeza et al., 1998).

\section{SUMMARY}

While early post-hatch feeding on the performance of other poultry species such as broilers has been extensively investigated, here we report an evaluation of this practice for Mule ducks. Overall at 0-7 days the cumulative feed intake and feed conversion differed among treatments. Further, the time of post-hatch feeding did not affect the weights of the bone, muscle and skin, and fat of the breast quarter. However, the weight of the bone for the leg and thigh quarter differed among the treatments (T1-T4). The $\mathrm{pH}_{24}$ was lower than the initial pH of both the breast and leg and thigh quarters overall feeding times.

\section{CONCLUSION}

Overall our results demonstrated that the body weights of the ducks increased over the 63 day period regardless of the time they were fed post-hatch. Additionally, the time the ducks were fed post-hatch did not influence the carcass performance of the ducks. Our research suggests that ducks be fed as early as possible post-hatch in order to enhance the growth performance.

\section{ACKNOWLEDGMENTS}

Authors thank Mr.Rashad Solomon, Mr.Adrian Paul, the workers at the University Field Station and the University of the West Indies, St. Augustine and the Department of Food Production for physical and financial support.

\section{REFERENCES}

Abed F, Karimi A, Sadeghi G, Shivazad M, Dashti S, Sadeghi-Sefidmazgi A. Do broiler chicks possess enough growth potential to compensate long-term feed and water depravation during the neonatal period?. South African Journal of Animal Science 2011;41:33-39.

Baeza E. La viande de canard :production et principals caractéristiques. INRA Productions Animales 1995;8(2):117-125.

Baeza E, Salichon MR, Marchie G, Juin H. Effect of sex on growth, technological,organoleptic characteristics of the Muscovy duck breast muscle. British Poultry Science 1998;39:398-403.

Careghi C, Tona K, Onagbesan O, Buyse J, Decuypere E, Bruggeman V. The effects of the spread of hatch,interaction with delayed feed access after hatch on broiler performance until seven days of age. Poultry Science 2005:84:1314-1320.

Casteel ET, Wilson JL, Buhr RJ, Sander JE. The influence of extended posthatch holding time, placement density on broiler performance. Poultry Science 1994;73(11):1679-1684.

Dutson RT. The measurement of ph in muscle,its importance to meat quality [technical article, 78903]. College Station: Texas Agricultural Experiment Station; 1983. p.92-97.

El-Husseiny OM, Abou El-Wafa S, El-Komy HMA. Influence of fasting or early feeding on broiler performance. International Journal of Poultry Science $2008 ; 7(3): 263-271$

Garden M. Broiler management for birds grown to low kill weights (1.51.8kg). Leola: Ross Technologies; 2008.

Glamoclija N, Starcevic M, Jelena J , Ivanovic J, Boskovic M, Djordevic J, et al. The effect of breed line,age on measurements of $\mathrm{pH}$ - value as meat quality parameter in breast muscles (m.pectoralis major) of broiler chickens. Procedia Food Science 2015;5:89-92

Hager JE, Beane WL. Post-hatch incubation-time,early growth of broilerchickens. Poultry Science 1983; 62(2):247-254.

Halevy O, Geyra A, Barak M, Uni Z, Sklan D. Early Starvation affects satellite cell proliferation, muscle growth in the chick. Journal of Nutrition 2000;130:858-864.

Halevy O, Nadel Y, Barak M, Rozenboim I, Sklan D. Early post-hatch feeding stimulates satellite cell proliferation in turkey poults. The Journal of Nutrition 2003;133(5):1376-1382.

Jacob $\mathrm{RH}$, Hopkins $\mathrm{DL}$. Techniques to reduce the temperature of beef muscle early in the post mortem period-a review. Animal Production Sciences 2014;54:482-493.

Lallo CHO, Ramraj S. The performance of improved pekin,mule duck strains reared under intensive conditions in a humid tropical environment. Proceedings of the International Congress on Tropical Agriculture; 2008 Nov 30- Dec 5; Trinidad: Faculty of Science \& Agriculture; 2008. p.309-317.

Lallo $\mathrm{CHO}$, Knights SR, Dasant S. The performance of three breeds (Muscovy, Mule,Pekin) of improved duck strains imported fromFrance into Trinidad 2007 [unpublished report].

Lawrie R. Meat science. $5^{\text {th }}$ ed. Elmsford: Pergammon Press;1991. p.58212.

Nir I, Levanon M. Effect of post-hatch holding time on performance,on residual yolk, liver composition. Poultry Science 1993;72(10):19941997.

Noy Y, Sklan D. Metabolic responses to early nutrition. Journal of Applied Poultry Research 1998a;7:437-451. 
Noy Y, Sklan D. Energy utilization in a newly hatched chick .Poultry Science 1999b:78:1750-1756.

Noy Y, Sklan D. Yolk, Exogenous feed utilization in the post-hatch chick. Poultry Science 2001;80:1490-1495.

Noy $Y$, Uni Z. Early nutritional strategies. World's Poultry Science Journal 2010;66(4):639-646

NRC. Nutrient requirements of poultry. $9^{\text {th }}$ rev. ed. Washington: National Academy Press; 1994.

Obun $\mathrm{CO}$, Osaguona PO. Influence of post-hatch starvation on broiler chick's productivity. ISOR Journal of Agriculture, Veterinary Science 2013;3(5):5-8.

Ristic MKD, Freudenreich P. Carcass value of ducks, geese in dependence of breed, age. Fleischwirtschaft 2006;86:107-110.

Rose S. Principles of poultry science. Kings Lynn: UK Briddles; 1997.

Saki AA. Effect of post-hatch feeding on broiler performance. International Journal of Poultry Science 2005;4(1):4-6.

Schweihofer JP. Carcass dressing percentage, cooler shrink. Michigan State University Extension; 2011. [cited 2019 Apr 12]. Available from: www. canr.msu.edu 2011.

Scott ML, Dean WF. Nutrition, management of ducks. Ithaca: Cornell University; 1991.
Stadleman WJ, Meinert. CF. Some factors affecting meat yield from young ducks. Poultry Science 1977;56:1145-1147.

Tona K, Bamelis F, De Ketelaere B, Bruggeman V, Moraes VMB, Buyse J. Effects of egg storage time on spread of hatch, chick quality, ${ }^{\prime}$ chick juvenile growth. Poultry Science 2003;82(5):736-741.

Tweed S. The hatch window [technical focus]. Siloam Springs: CobbVantress; 2005. v.2.

Van Laack RJLM. Determinants of ultimate $\mathrm{pH}$ of meat, poultry. Reciprocation Session; 2000 [cited 2018 Sep 10]. Available from: https://www. meatscience.org/docs/default-source/publicationsresources/rmc/2000/determinants-of-ultimate-ph-of-meat-and-poultry. pdf?sfvrsn=e358bbb3_2.

Van Laack RLJM, Kauffman RG. Glycolytic potential of red, soft, exudative pork longissimus muscle. Journal of Animal Science 1999;77:29712973.

Veltmann JR, Sharlin JS. Influence of water deprivation on water consumption, growth, carcass characteristics of ducks. Poultry Science 1981;60:637-642

Wilson BJ. The performance of male ducklings given starter diets with different concentration of energy, protein. British Poultry Science 1975:16:617-625. 
